\title{
\begin{tabular}{l|l|l} 
Jurnal Eksplorasi Akuntansi & $\begin{array}{l}\text { ISSN : 2656-3649 (Online) } \\
\text { hol. 1, No 1, Seri A, Februari 2019, Hal 90-108 }\end{array}$
\end{tabular}
}

\section{PENGARUH GENDER, BUDAYA, DAN FAKTOR LINGKUNGAN TERHADAP ETHICAL BELIEFS}

(Studi Empiris pada Mahasiswa S1 Akuntansi di Kota Padang)

\author{
Dio Septiawan ${ }^{1}$, Herlina Helmy ${ }^{2}$, Salma Taqwa ${ }^{3}$ \\ ${ }^{1)}$ Alumni Jurusan Akuntansi Fakultas Ekonomi Universitas Negeri Padang \\ ${ }^{2,3)}$ Jurusan Akuntansi Fakultas Ekonomi Universitas Negeri Padang \\ *Korespondensi: dio_septiawan@yahoo.com
}

\begin{abstract}
The purpose of this study was to investigate the influence of gender, culture, the campus environment, and the home environment against ethical beliefs. This study focused on students majoring in accounting in the city of Padang has taken the course of the audit and has not yet taken including the course of the audit. Data collection methods are purposive sampling. Types of data used in this research is the data subject in which type of research data in the form of accounting students in four universities in the city of Padang, Padang State University, Andalas University, Bung Hatta University, and Putra Indonesia University. The data source in the research is primary data. In this research show that there are not prove that women tend to be more ethical in an Ethical audit accounting student ethical beliefs., meanwhile the result of the study show that there are positive influences between culture, Campus environment, and Home environment against the Ethical beliefs has taken courses on auditing and has taken including the course of the audit in students accounting in the city of Padang.
\end{abstract}

Keywords: Campus environment; Culture; Ethical Beliefs; Gender; Home environment

How to cite (APA $6^{\text {th }}$ style)

Septiawan, D., Helmy, H., \& Taqwa, S. (2019). Pengaruh Gender, Budaya, Dan Faktor Lingkungan Terhadap Ethical Beliefs (Studi Empiris pada Mahasiswa S1 Akuntansi di Kota Padang). Jurnal Eksplorasi Akuntansi, 1(1) Seri A, 90-108.

\section{PENDAHULUAN}

Di era globalisasi saat sekarang ini, akuntan dituntut untuk bekerja secara profesional. Kemampuan dan keahlian khusus merupakan hal yang harus dimiliki oleh seorang akuntan. Seorang akuntan juga harus memiliki etika profesional yang tinggi dalam menjalankan profesinya. Etika profesional yang tinggi dibutuhkan untuk meningkatkan kepercayaan publik terhadap kualitas jasa yang diberikan. Sehubungan dengan itu, maka setiap akuntan dituntut mempunyai pengetahuan, pemahaman, dan menerapkan etika secara memadai dalam pelaksanaan pekerjaan profesionalnya. Pekerjaan profesional harus dikerjakan berdasarkan pada standar moral dan etika profesi yang telah ditetapkan. Dengan sikap profesionalnya, maka akuntan mampu menghadapi berbagai tekanan yang muncul dari dalam maupun diluar dirinya. Dalam Theory Planned Behavior yang diusulkan oleh Ajzen (1985) menyatakan bahwa sikap individu terhadap etika ditentukan oleh keyakinan (beliefs) yang sudah dimilikinya. 
Ramdhani (2008) mengemukakan bahwa sikap akan terbentuk jika individu mempunyai keyakinan logis berkaitan dengan objek sikap tertentu. Keyakinan atau beliefs adalah penilaian subjektif yang mungkin dimiliki individu atau subjective probability judgements. Keyakinan (beliefs) yang dibahas dalam penelitian ini mengenai ethical beliefs akuntan. Dimana Peterson et al. (2001) menyatakan bahwa ethical beliefs merupakan penilaian subjektif yang dimiliki individu mengenai perilaku etis dan perilaku tidak etis. Penilaian etis yang dimiliki sesorang bisa menjadi penilaian yang relatif. Seseorang mungkin bisa menganggap bahwa hal yang dilakukan adalah hal yang benar, namun menurut penilaian orang lain hal tersebut salah. Hal ini didukung oleh Velasquez (2005:20) yang menyatakan relativisme etika adalah pandangan bahwa tidak ada prinsip moral yang benar secara universal, kebenaran semua prinsip moral bersifat relatif terhadap budaya atau pilihan individu, maka masyarakat yang berbeda akan memiliki ethical beliefs yang berbeda. Apakah tindakan tersebut benar atau salah secara moral, tergantung kepada pandangan dan keyakinan (beliefs) yang dimiliki masyarakat tersebut.

Beberapa tahun terakhir serentetan perusahaan di dunia mengalami kebangkrutan akibat perilaku tidak etis akuntan seperti: kasus HIH Insurance dan Tel di Australia; kasus skandal keuangan Enron (2001); Helth South (2003); WordCome dan Global Crossing Di Amerika. Di Indonesia, kasus tentang pelanggaran etika yang melibatkan akuntan publik dengan melanggar Standar Profesi Akuntan Publik (SPAP) sendiri telah mulai bermunculan. Hal tersebut mengakibatkan krisis kepercayaan masyarakat indonesia terhadap akuntan. Salah satu kasus pelanggaran etika akuntan adalah kasus Auditor Badan Pemeriksa Keuangan (BPK). Kasus tersebut menjadi pukulan sekaligus bahan evaluasi internal bagi lembaga audit BPK RI dalam menegakan akuntabilitas sesuai prinsip independensi, integritas dan profesional auditor (www.kompas.com).

Kasus tersebut membuktikan bahwa akuntan gagal menjalankan perannya sebagai auditor independen. Auditor utama Keuangan Negara seharusnya memahami dan memegang teguh Standar Profesi Akuntan Publik (SPAP) dengan baik, namun pada keyataannya akuntan tidak berperilaku etis dalam membuat keputusan. Ini sebuah bukti bahwa profesi akuntan yang seharusnya tunduk kepada kode etik malah melanggar kode etik yang ada dan mengabaikan perilaku etis demi kepentingan dirinya (Ahmadi, 2003). Perilaku dan niat yang dimiliki oleh akuntan terkadang tidak konsisten dengan ethical beliefs yang dimiliki. Mungkin saja, seseorang akuntan memiliki ethical beliefs tentang suatu hal yang merupakan perbuatan yang tidak etis dari segi niat. Akuntan tidak berniat untuk melakukan perbuatan yang tidak etis, namun dalam kenyataannya akuntan masih berperilaku tidak etis. Hal ini didukung oleh Hunt dan Vittel (1992) yang meyatakan bahwa perilaku kadang-kadang berbeda dari niat sebelumnya. Hal tersebut berarti, meskipun seseorang individu melihat alternatif tertentu sebagai yang paling etis, orang tersebut mungkin saja berniat untuk memilih alternatif lain karena konsekuensi pilihan tertentu.

Ethical beliefs seseorang bisa berbeda-beda karena pembentukan ethical beliefs dibentuk oleh faktor-faktor internal dan faktor lingkungan. Menurut Perryer dan Jordan (2002) faktor internal yang mempengaruhi ethical beliefs adalah gender dan budaya, sedangkan faktor lingkungan yang mempengaruhi ethical beliefs yaitu lingkungan kampus dan lingkungan rumah.

Faktor pertama adalah gender, perbedaan gender dapat memberikan ethical beliefs yang berbeda dalam melihat situasi tidak etis yang terjadi. Menurut Febrianti (2010), gender merupakan perbedaan yang terlihat antara kaum laki-laki dan perempuan dari nilai dan sifatnya.

Faktor kedua yang mempengaruhi ethical beliefs akuntan adalah budaya. Menurut Sarwono (2015) budaya adalah suatu set dari sikap, perilaku dan simbol-simbol yang dimiliki 
bersama oleh orang-orang dan biasanya dikomunikasikan dari satu generasi ke generasi berikutnya.

Budaya Minangkabau (orang Minang) merupakan salah satu dari sepuluh kelompok budaya yang besar di Indonesia (BPS, 2010). Orang Minang mempunyai pandangan hidup sendiri yang berbeda dengan pandangan hidup budaya lainnya. Pandangan hidup orang Minang tertuang dalam ketentuan yang disebut dengan adat minangkabau 'adat basandi syara', syara" basandi kitabullah" (adat bersendikan hukum, hukum bersendikan Al-Qur'an) yang berarti adat berlandaskan ajaran islam (Navis, 1984). Dapat disimpulkan bahwa orang Minang merupakan penganut agama islam yang taat. Mereka boleh dikatakan tidak mengenal unsurunsur keyakinan (beliefs) lainnya. Sehingga dapat disimpulkan bahwa budaya mempengaruhi ethical beliefs seseorang.

Lingkungan kampus pun menjadi faktor lingkungan yang mempengaruhi ethical beliefs seseorang. Lingkungan kampus adalah lingkungan yang meliputi semua hal yang berpengaruh dan bermakna bagi mahasiswa saat menjalani proses perkuliahan di kampus, baik itu lingkungan sosial maupun lingkungan non-sosial. Lingkungan kampus akan membentuk sikap dan perilaku mahasiswanya. Pada dasarnya lingkungan kampus yang baik bisa mempengaruhi ethical beliefs seseorang melalui kegiatan belajar. Ini berarti bahwa, lingkungan kampus yang baik dapat membentuk ethical beliefs mahasiswanya. Penelitian yang dilakukan Perryer dan Jordan (2002) menemukan lingkungan mempengaruhi ethical beliefs seseorang. Faktor lingkungan yang mempengaruhi ethical beliefs selain lingkungan kampus adalah lingkungan rumah (Perryer dan Jordan 2002).

Lingkungan rumah merupakan lingkungan pertama seseorang dalam kehidupan manusia, tempat seseorang melakukan proses pembelajaran dan menyatakan diri sebagai manusia sosial di dalam hubungan interaksi dengan kelompoknya. Keluarga mempunyai peranan yang sangat penting dalam membantu individu untuk melakukan proses sosialisasi melalui pembelajaran dan penyesuaian diri, dalam berfikir, bertindak, berperilaku dan bersikap secara baik di masyarakat (Utami, 2011). Hal tersebut menandakan ethical beliefs seseorang dipengaruhi lingkungan dimana orang tersebut berinteraksi.

Ponemon dan Glazer (1990) menyatakan bahwa perilaku etis akuntan publik akan dibentuk sejak masa kuliah, dimana mereka ditanamkan nilai-nilai profesional melalui sosialisasi profesi. Sehingga perguruan tinggi akan mencetak akuntan yang tidak hanya berkompetensi tetapi juga memiliki ethical beliefs yang bagus untuk menjadi para profesional di masa depan. Oleh karena itu, pentingnya etika dalam suatu profesi membuat profesi akuntansi lebih memfokuskan perhatiannya pada ethical beliefs para mahasiswa akuntansi sebagai titik awal dalam meningkatkan ethical beliefs terhadap profesi akuntansi (Elias, 2010).

Pada penelitian ini, peneliti ingin mengetahui mengenai pengaruh gender, budaya, dan faktor lingkungan terhadap ethical beliefs mahasiswa S1 akuntansi di kota Padang. Penekanan penelitian ini adalah pada dimensi aspek demografi yang meliputi gender, budaya, dan faktor lingkungan yang meliputi pengaruh lingkungan kampus dan lingkungan rumah sebagai bagian dari aspek individual yang dapat mempengaruhi ethical beliefs mahasiswa S1 akuntansi di kota Padang. Objek dalam penelitian ini adalah mahasiswa S1 akuntansi tingkat awal dan mahasiswa S1 akuntansi tingkat akhir di kota Padang. Alasan pemilihan objek tersebut dikarenakan mahasiswa akuntansi tingkat akhir telah mengambil mata kuliah yang memuat etika sehingga lebih memahami perilaku etis dan tidak etis akuntan. Sebaliknya, mahasiswa akuntansi tingkat awal belum mengambil mata kuliah yang memuat etika sehingga belum memahami perilaku etis dan tidak etis akuntan. Berdasarkan alasan tersebutlah peneliti ingin melihat apakah terdapat perbedaan ethical beliefs antara mahasiswa S1 akuntansi tingkat awal dengan mahasiswa S1 akuntansi tingkat akhir di kota Padang. 
Penelitian ini dilakukan karena semakin banyaknya kasus pelanggaran etika yang terjadi baik di Indonesia maupun didunia yang melibatkan profesi akuntan sehingga menyebabkan krisis kepercayaan masyarakat terhadap profesi akuntan. Sehingga peneliti tertarik untuk meneliti tentang ethical beliefs dan faktor-faktor yang mempengaruhinya baik faktor demografi seperti: gender dan budaya maupun faktor lingkungan seperti: pengaruh lingkungan kampus dan lingkungan rumah yang mungkin berpengaruh. Berdasarkan uraian diatas, maka penulis memberi judul penelitian ini dengan: "Pengaruh Gender, Budaya, dan Faktor Lingkungan terhadap Ethical Beliefs".

\section{REVIU LITERATUR DAN HIPOTESIS}

\section{Theory Planned Behavior (TPB)}

Theory Planned Behavior (teori perilaku yang direncanakan) adalah teori yang menghubungkan keyakinan dan perilaku. Ajzen (2005) mengusulkan teori ini untuk memperbaiki kekuatan prediksi dari teori tindakan beralasan termasuk yang dirasakan kontrol perilaku. Tujuan dan manfaat dari teori ini adalah untuk memprediksi dan memahami pengaruh-pengaruh motivasi perilaku, baik keinginan individu itu sendiri maupun bukan keinginan dari individu tersebut. Teori ini terdiri dari tiga dasar determinan, yaitu:

1) Sikap (attitude), ini mengacu pada sikap terhadap perilaku ditentukan oleh keyakinan menegenai konsekuensi dari suatu perilaku atau keyakinan-keyakinan perilaku (Ajzen, 2005).

2) Norma subyektif (subjective norm), merupakan persepsi individu terhadap harapan dari orang-orang yang berpengaruh dalam kehidupannya mengenai dilakukan atau tidaknya perilaku tertentu (Ramdhani, 2011).

3) Kontrol perilaku (perceived behavioual control), Ajzen (2005) menyatakan kontrol perilaku merupakan persepsi individu mengenai mudah atau sulitnya mewujudkan suatu perilaku tertentu.

\section{Ethical Beliefs}

\section{Pengertian ethical beliefs}

Keyakinan atau beliefs adalah penilaian subjektif yang mungkin dimiliki individu atau subjective probability judgements. Menurut Peterson et al. (2001) ethical beliefs merupakan penilaian subjektif yang dimiliki individu mengenai perilaku etis dan perilaku tidak etis. Penilaian etis yang dimiliki seseorang bisa menjadi penilaian yang relatif. Seseorang mungkin bisa menganggap bahwa hal yang dilakukan adalah hal yang benar, namun menurut penilaian orang lain hal tersebut salah.hal tersebut didukung oleh menurut Velasquez (2005: 20) menyatakan relativisme etis adalah teori bahwa, karena masyarakat yang berbeda memiliki keyakinan etis yang berbeda. Tidak ada cara yang rasional untuk menentukan apakah sebuah tindakan secara moral benar atau salah kecuali bertanya apakah orang dari masyarakat ini atau itu percaya bahwa tindakan itu secara moral benar atau salah.

\section{Indikator ethical beliefs}

Rawwas et al. (2007) yang terdiri dari pernyataan-pernyataan mengenai kecurangan akademik. kecurangan akademik tersebut dibagi menjadi empat dimensi, yaitu:

1)Menerima dan menyalahkan ketidakjujuran akademik

2)Mendapatkan keuntungan yang tidak adil

3)Fabrikasi informasi

4)Mengabaikan praktek-praktek yang berlaku. 


\section{Gender}

Secara etimologis Kata "gender" berasal dari bahasa inggris, gender berarti "jenis kelamin", dimana artinya kurang sesuai karena dengan demikian gender disamakan pengertiannya dengan sex yang berarti jenis kelamin. Sarwono (2015:106-107) menjelaskan bahwa "konsep jenis kelamin mengacu kepada faktor biologik dan fisiologik (fall) dari jenis kelamin, sedangkan gender mengacu kepada perilaku atau pola aktivitas yang dianggap layak bagi seseorang perempuan atau laki-laki menurut masyarakat atau budaya". Dalam Webster's New World Dictionar, gender diartikan sebagai perbedaan yang tampak antara laki-laki dan perempuan dilihat dari segi nilai dan tingkah laku. Dalam Women's Studies Encyclopedia dijelaskan bahwa gender adalah konsep kultural yang berupaya membuat perbedaan dalam hal peran, perilaku, mentalis, dan karakteristik emosional laki-laki dan perempuan yang berkembang dalam masyarakat (Fitrianingsih, 2011) dalam Nugraha (2015). Gender muncul akibat pengaruh sosial budaya dan kebiasaan-kebiasaan yang berkembang dalam masyarakat setempat.

Perbedaan peran dan perilaku antara laki-laki dan perempuan dapat disebabkan oleh beberapa hal, seperti sosialisasi, budaya yang berlaku, serta kebiasaan yang ada. Pandangan tentang gender dapat diklasifikasikan ke dalam dua stereotipe, yaitu Sex Role Stereotypes dan Managerial Stereotypes. Pengertian klasifikasi stereotypes merupakan proses pengelompokan individu kedalam suatu kelompok, dan pemberian atribut karakteristik pada individu berdasarkan anggota kelompok (Ulfa, 2011) dalam Nugraha (2015). Berdasarkan Sex Role Stereotypes, laki-laki dipandang lebih berorientasi pada pekerjaan, mampu bersikap obyektif, independen, dan pada umumnya mempunyai kemampuan yang lebih dalam pertanggungjawaban manajerial jika dibandingkan dengan perempuan. Sedangkan perempuan dipandang lebih pasif, lemah lembut, memiliki orientasi pada pertimbangan dan posisinya pada pertanggungjawaban dalam organisasi lebih rendah dibandingkan laki-laki. Managerial Stereotypes memberikan pengertian manajer yang sukses adalah seseorang yang memiliki sikap, perilaku, dan temperamen, dimana sikap ini pada umumnya lebih dimiliki oleh laki-laki.

\section{Budaya}

\section{Pengertian Budaya}

Menurut Kamus Besar Bahasa Indonesia, kata budaya berasal dari bahasa sanskerta "bodhya" yang berarti akal budi. Menurut Schiffman (2008) budaya adalah kumpulan tentang keyakinan, nilai, adat yang berfungsi untuk mengarahkan perilaku konsumen di anggota masyarakat tertentu. Kotler dan Keller (2007) mengemukakan bahwa budaya adalah penentu keinginan dan perilaku referensi, dan perilaku manusia ditentukan yang paling mendasar.

Menurut Sarwono (2015:3) budaya adalah suatu set dari sikap, perilaku dan simbolsimbol yang dimiliki bersama oleh orang-orang dan biasanya dikomunikasikan dari satu generasi ke generasi berikutnya. Manusia tidak lahir dengan membawa budayanya, melainkan budaya tersebut diwariskan dari generasi ke generasi.

\section{BudayaMinang}

Suku Minangkabau merupakan salah satu suku bangsa yang besar, mempunyai pandangan hidup yang berbeda dengan pandangan hidup suku-suku lainnya. Pandangan hidup orang Minang tertuang dalam Adat Minangkabau.

Kelompok etnis masyarakat Minangkabau mempunyai adat istiadat dan filsafat hidup yang kuat. Agama islam merupakan dasar dari adat dan filsafah hidup dari masyarakat Minang, seperti yang tertuang dalam salah satu dari prinsip hidup mereka "adat basandi syara', syara" basandi kitabullah" (adat bersendikan hukum, hukum bersendikan Al-Qur'an) yang berarti 
adat berlandaskan ajaran islam (Mara, 2010). Masyarakat Minang merupakan penganut agama islam yang taat. Mereka boleh dikatakan tidak mengenal unsur-unsur kepercayaan lainnya.

\section{Lingkungan Kampus}

lingkungan kampus adalah lingkungan yang meliputi lingkungan fisik, lingkungan sosial,dan lingkungan akademis. Lingkungan fisik meliputi kelas, sarana dan prasarana belajar yang ada, sumber-sumber belajar, dan media belajar. Lingkungan sosial menyangkut hubungan mahasiswa dengan teman-temannya, dosen-dosennya, serta staf akademik kampus yang lain. Lingkungan akademis, yaitu sarana pelaksanaan kegiatan belajar-mengajar, berbagai kegiatan kokurikuler, dan lain sebagainya.

Berdasarkan beberapa pendapat sebagaimana telah diuraikan dapat disimpulkan bahwa Lingkungan kampus adalah lingkungan yang meliputi semua hal yang berpengaruh dan bermakna bagi mahasiswa saat menjalani proses perkuliahan di kampus, baik itu lingkungan sosial maupun lingkungan non-sosial

\section{Lingkungan Rumah \\ Pengertian lingkungan rumah}

Lingkungan Rumah adalah sebuah lembaga sosial penting dalam masyarakat yang merupakan kelompok sosial pertama dalam kehidupan manusia, tempat seseorang melakukan proses pembelajaran dan menyatakan diri sebagai manusia sosial di dalam hubungan interaksi dengan kelompoknya (Utami, 2011). Ahmadi (2009:221) menyatakan "keluarga adalah kelompok primer yang paling penting dalam masyarakat.

Keluarga mempunyai peranan yang sangat penting dalam membantu individu untuk melakukan proses sosialisasi melalui pembelajaran dan penyesuaian diri, dalam berfikir, bertindak, berperilaku dan bersikap secara baik di masyarakat. Berdasrkan penjelasan diatas, lingkungan keluarga mempengaruhi perkembangan pemikiran seseorang.

\section{Indikator lingkungan rumah}

Menurut Slameto (2003: 62-66) faktor-faktor keluarga dibedakan menjadi lima, antara lain :

1) Cara Orang Tua Mendidik

2) Relasi antar Anggota Keluarga

3) Suasana Rumah

4) Keadaan Ekonomi Keluarga

5) Pengertian Orang Tua

6) Latar Belakang Orang Tua

\section{Pengembangan Hipotesis}

\section{Pengaruh Gender terhadap Ethical Beliefs pada Mahasiswa S1 Akuntansi di Kota Padang}

Gender merupakan perbedaan yang terlihat antara kaum laki-laki dan perempuan dari nilai dan sifatnya (Febrianti, 2010). Pendekataan sosialisasi gender menyatakan bahwa lakilaki dan perempuan membawa seperangkat nilai dan sifat yang berbeda kedalam lingkungan kerja maupun lingkungan belajar. Perbedaan nilai dan sifat berdasarkan gender akan mempengaruhi laki-laki dan perempuan dalam mengambil keputusan dan praktik. Laki-laki akan bersaing mencapai kesuksesan dan cenderung melanggar aturan yang ada karena mereka memandang pencapaian prestasi sebagai suatu persaingan. Berkebalikan dengan laki-laki yang mementingkan hasil akhir (relative performance), perempuan lebih mementingkan selfperformance. Perempuan akan menitikberatkan pada pelaksanaan tugas dengan baik dan 
hubungan kerja yang harmonis, sehingga perempuan akan lebih patuh terhadap peraturan dan mereka lebih kritis terhadap orang-orang yang melanggar aturan tersebut (Febrianti, 2010).

Penelitian yang dilakukan oleh Hunt (1997); Dawson (1997); Peterson et al. (2001) gender merupakan faktor penting dalam ethical beliefs dimana ditemukan perempuan memiliki ethical beliefs yang lebih tinggi dibandingkan laki-laki. Oleh karena itu, ethical beliefs mahasiswa akuntansi perempuan akan cenderung lebih tegas dalam menyikapi situasi yang tidak etis yang terjadi di sekitarnya dibandingkan dengan mahasiswa akuntansi laki-laki. Hal tersebut mengindikasikan bahwa perbedaan gender berakibat pada penilaian yang berbeda antara mahasiswa akuntansi laki-laki dan mahasiswa akuntansi perempuan terhadap ethical beliefs, terutama mahasiswa akuntansi perempuan memiliki ethical beliefs yang lebih baik dibandingkan mahasiswa akuntansi laki-laki. Sehingga hipotesis pada penelitian ini adalah sebagai berikut:

$\mathbf{H}_{1}$ : Mahasiswa akuntansi perempuan memiliki ethical beliefs yang lebih baik dibandingkan mahasiswa akuntansi laki-laki

\section{Pengaruh Budaya terhadap Ethical Beliefs pada Mahasiswa S1 Akuntansi di Kota Padang}

Budaya adalah suatu set dari sikap, perilaku dan simbol-simbol yang dimiliki bersama oleh orang-orang dan biasanya dikomunikasikan dari satu generasi ke generasi berikutnya (Sarwono, 2015). Budaya terbentuk dari lingkungan tempat dimana seseorang berinteraksi Hunt dan Vitell (1993). Ini berarti bahwa budaya mempengaruhi perilaku atau sikap seseorang melalui nilai-nilai yang dibawanya melalui lingkungan sekitar. Rawwas et al. (2014) melakukan penelitian untuk melihat perbedaan ethical beliefs antara budaya Amerika Serikat dan Hongkong dan menemukan bahwa budaya berpengaruh terhadap ethical beliefs. Mahasiswa MBA Amerika Serikat cenderung bertindak tidak etis sedangkan mahasiswa MBA Hongkong cenderung bertindak secara moral.

Penelitian tersebut didukung oleh Hoffman et al. (2002) yang menyatakan budaya menjadi prediktor signifikan dari perilaku atau sikap. Di indonesia, terdapat berbagai budaya yang besar salah satunya budaya Minang. Orang Minang mempunyai pandangan hidup sendiri yang berbeda dengan pandangan hidup budaya lainnya. Pandangan hidup orang Minang tertuang dalam ketentuan yang disebut dengan adat minangkabau "adat basandi syara', syara" basandi kitabullah" (adat bersendikan hukum, hukum bersendikan Al-Qur'an) yang berarti adat berlandaskan ajaran islam (Navis, 1984). Dapat disimpulkan bahwa orang Minang merupakan penganut agama islam yang taat sehingga akan memiliki ethical beliefs yang lebih baik dari budaya non minang karena hanya memiliki satu kepercayaan. Sehingga dapat disimpulkan bahwa budaya Minang memiliki ethical beliefs yang lebih baik dari budaya non Minang. Sehingga hipotesis pada penelitian ini adalah sebagai berikut:

$\mathbf{H}_{2}$ : Mahasiswa akuntansi Minang memiliki ethical beliefs yang lebih baik dibandingkan mahasiswa akuntansi non Minang

\section{Pengaruh Lingkungan Kampus terhadap Ethical Beliefs pada Mahasiswa S1 Akuntansi di Kota Padang}

Lingkungan kampus adalah lingkungan yang meliputi semua hal yang berpengaruh dan bermakna bagi mahasiswa saat menjalani proses perkuliahan di kampus, baik itu lingkungan sosial maupun lingkungan non-sosial. Ini berarti bahwa, lingkungan kampus yang baik dapat memberikan kenyamanan kepada mahasiswa dalam pembentukan ethical beliefs selama masa kuliah. Dukungan lingkungan kampus yang baik secara sosial maupun non-sosial akan membentuk ethical beliefs yang baik pula. 
Menurut Perryer dan Jordan (2002) lingkungan menjadi prediktor perilaku etis. Ini menandakan bahwa ethical beliefs mahasiswa dipengaruhi lingkungan tempat mahasiswa belajar. Semakin baik lingkungan kampus mahasiswa maka mahasiswa tersebut akan memiliki ethical beliefs yang baik. Hal tersebut didukung oleh Zey-Ferrell et al. (1979) dalam Peterson (2002) yang menyatakan bahwa ethical beliefs seseorang dipengaruhi oleh lingkungan tempat mereka berinteraksi. Berdasarkan uraian diatas dapat disimpulkan bahwa lingkungan kampus mempengaruhi ethical beliefs mahasiswa. Sehingga hipotesis pada penelitian ini adalah sebagai berikut:

H3: Lingkungan kampus berpengaruh signifikan positif terhadap ethical beliefs pada mahasiswa akuntansi

\section{Pengaruh Lingkungan Rumah terhadap Ethical Beliefs pada Mahasiswa S1 Akuntansi di Kota Padang}

Lingkungan Rumah adalah sebuah lembaga sosial penting dalam masyarakat yang merupakan kelompok sosial pertama dalam kehidupan manusia, tempat seseorang melakukan proses pembelajaran dan menyatakan diri sebagai manusia sosial di dalam hubungan interaksi dengan kelompoknya (Utami, 2011). Hal ini tampaknya mungkin bahwa nilai-nilai yang diperoleh dari rumah melalui proses sosialisasi selama masa kanak-kanak dan melalui perkembangan moral pada umumnya akan mempengaruhi sikap dalam masalah etika (Peterson et al., 2001). Hal ini didukung oleh Perryer dan Jordan (2002) menyatakan lingkungan rumah menjadi prediktor perilaku etis. Artinya, apabila sosialisasi seseorang di lingkungan rumahnya baik maka seseorang tersebut akan memiliki ethical beliefs yang baik pula. Sehingga hipotesis pada penelitian ini adalah sebagai berikut:

H4: lingkungan rumah berpengaruh signifikan positif terhadap ethical beliefs pada mahasiswa akuntansi.

\section{Terdapat Perbedaan Ethical Beliefs antara Mahasiswa S1 Akuntansi Tingkat Awal dan Mahasiswa S1 Akuntansi Tingkat Akhir di Kota Padang}

Mahasiswa merupakan individu yang belajar di perguruan tinggi (KBBI, 2018). Mahasiswa dapat dibagi menjadi menjadi mahasiswa tingkat awal dan mahasiswa tingkat akhir. Mahasiswa tingkat awal yaitu mahasiswa yang masih berada pada tahun pertama atau mahasiswa baru sedangkan mahasiswa tingkat akhir yaitu mahasiswa yang berada pada tahun terakhir pendidikan, atau mahasiswa yang sudah menempuh hampir seluruh mata kuliah dan atau sedang mengerjakan skripsi. Berdasarkan definisi tersebut dapat kita simpulkan bahwa yang menjadi perbedaan antara mahasiswa tingkat awal dan tingkat akhir disebabkan pengalaman dan mata kuliah yang telah diambil. Sehingga akan terdapat perbedaan penilaian etis antara mahasiswa tingkat awal dengan mahasiswa tingkat akhir.

Penelitian yang dilakukan oleh Yulianti dan Fitriany (2005); Risa (2010) menyatakan bahwa mahasiswa tingkat akhir memiliki persepsi etis yang lebih baik dibandingkan dengan mahasiswa tingkat awal. Hal ini menunjukkan bahwa pendidikan etika yang terkandung dalam beberapa matakuliah yang diajarkan mempunyai dampak positif terhadap prilaku etika mahasiswa. Berdasarkan penjelasan tersebut, maka mahasiswa akuntansi tingkat akhir akan memiliki ethical beliefs yang lebih baik dari mahasiswa akuntansi tingkat awal. Sehingga hipotesis dalam penelitian ini adalah sebagai berikut:

H5: Mahasiswa akuntansi tingkat akhir memiliki ethical beliefs yang lebih baik dari mahasiswa akuntansi tingkat awal. 

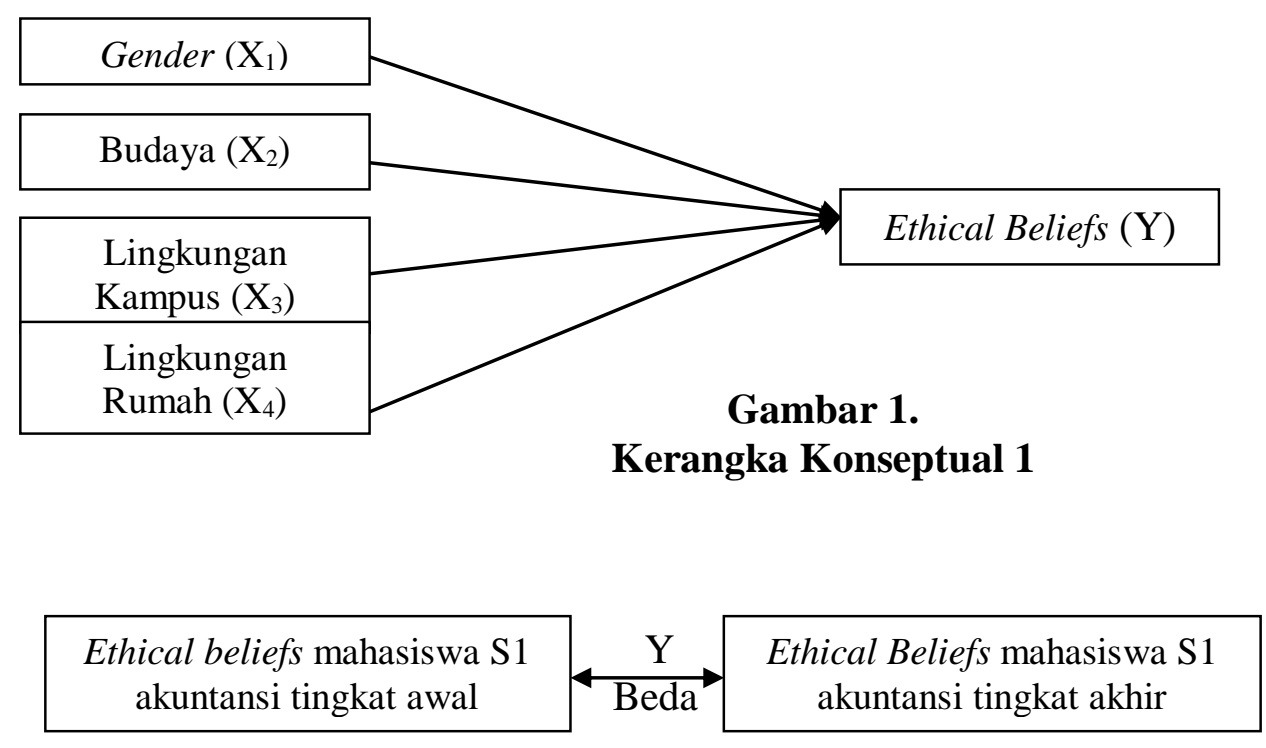

\section{Gambar 2. \\ Kerangka Konseptual II}

\section{METODE PENELITIAN}

Populasi adalah mahasiswa S1 akuntansi di kota Padang. Populasi dalam penelitian ini adalah mahasiswa akuntansi yang telah mengambil mata kuliah audit dan yang belum mengambil mata kuliah audit. Sampel merupakan suatu himpunan bagian dari unit populasi. Pengambilan sampel dalam penelitian ini dilakukan secara purposive sampling, artinya sampel dipilih berdasarkan pertimbangan subyektif penelitian dimana persyaratan yang dibuat sebagai kriteria harus dipenuhi sebagai sampel. Adapun kriteria sampel pada penelitian ini adalah: (a) mahasiswa akuntansi yang sedang kuliah di Fakultas Ekonomi Universitas Negeri Padang, Universitas Andalas, Universitas Bung Hatta, dan Universitas Putra Indonesia. (b) Mahasiswa S1 akuntansi tingkat awal (tahun masuk 2018, 2017 dan 2016), dimana mahasiswa dianggap belum memahami perilaku etis dan tidak etis karena belum lulus mata kuliah audit dan mahasiswa S1 akuntansi tingkat akhir (tahun masuk 2015) dimana mahasiswa dianggap memahami perilaku etis dan perilaku tidak etis karena telah lulus mata kuliah audit.

Jenis data yang digunakan dalam penelitian ini adalah data subjek. Data subjek adalah jenis data penelitian yang berupa opini, sikap, pengalaman, atau karakteristik sekelompok seseorang yang menjadi subjek penelitian (responden). Sumber data dalam penelitian adalah data primer. Data primer yang digunakan dalam bentuk kuisioner yang terdiri dari item-item pertanyaan.

\section{HASIL DAN PEMBAHASAN \\ Hasil Uji Aumsi Klasik \\ Uji Normalitas}

Dari hasil pengolahan data SPSS didapat bahwa nilai Sig. Variabel gender, budaya, lingkungan kampus, dan lingkungan rumah sebesar 0,164 dimana lebih besar dari 0,05, maka dapat disimpulkan bahwa nilai residual regresi terdistribusi normal. 
Dari output SPSS didapat nilai Asymp. Sig. Ethical beliefs mahasiswa tingkat akhir sebesar 0,555 dan nilai Asymp. Sig. Ethical beliefs mahasiswa tingkat awal sebesar 0,063, dimana kedua nilai tersebut lebih besar dari 0,05, maka dapat disimpulkan bahwa data kedua sample terdistribusi normal.

\section{Uji Heterokedastisitas}

Berdasarkan uji heterokedastisitas data gender, budaya, lingkungan kampus dan lingkungan rumah diperoleh hasil seperti gambar 3 berikut ini :

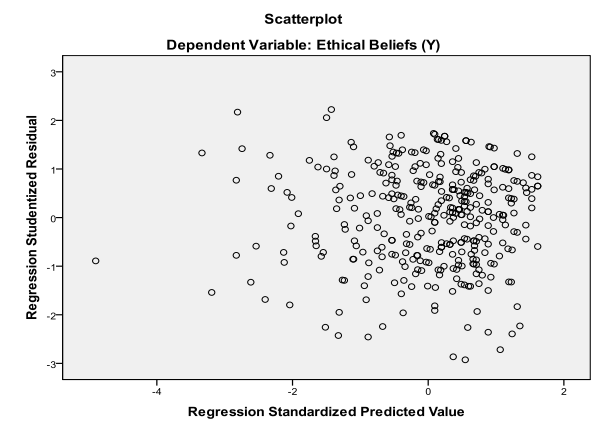

Gambar 3

Dari scatterplot diatas titik-titik menyebar secara acak dan tidak membentuk suatu pola tertentu maka tidak terjadi heteroskedastisitas.

\section{Uji Multikoloniaritas}

Berdasarkan hasil pengolahan data SPSS dapat dilihat bahwa variabel gender (X1) dengan VIF 1,080, variabel budaya (X2) dengan VIF 1,108, variabel lingkungan kampus (X3) dengan VIF 1,130, dan variabel lingkungan rumah (X4) dengan VIF 1,171, dimana keempat nilai VIF lebih kecil dari 10 dan nilai tolerance variabel gender (X1) dengan nilai tolerance 0,926 , variabel budaya (X2) dengan nilai tolerance 0,903 , variabel lingkungan kampus (X3) dengan nilai tolerance 0,885 , dan variabel lingkungan rumah $(\mathrm{X} 4)$ dengan nilai tolerance 0,854, dimana keempat nilai tolerance lebih besar dari 0,1, maka dapat disimpulkan bahwa tidak terjadi multikolinieritas.

\section{Uji Homogenitas}

Berdasarkan hasil pengolahan data SPSS diketahui bahwa nilai signifikansi (sig) dari data ethical beliefs sebesar 0,072. Dapat disimpulkan bahwa data ethical beliefs mempunyai varian yang homogen karena $\operatorname{sig}>\alpha$.

\section{Hasil Analisis Regresi}

Dari hasil pengolahan data SPSS, didapat nilai sig sebesar $0,000<0,05$ sehingga model regresi yang dipakai dapat digunakan. Pada Tabel 3.13 dapat dianalisis model estimasi sebagai berikut :

$$
\begin{array}{cl}
\mathbf{Y}=\mathbf{6 1 , 7 0 0}+\mathbf{0 , 2 5 8} \mathbf{X}_{\mathbf{1}}+\mathbf{3 , 3 5 3} \mathbf{X}_{\mathbf{2}}+\mathbf{0 , 7 3 1} \mathbf{X}_{\mathbf{3}}+\mathbf{0 , 2 9 9} \mathbf{X}_{\mathbf{4}} \\
\text { Dimana : } & \text { Ethical Beliefs } \\
\mathrm{Y} & =\text { Gender } \\
\mathrm{X}_{1} & =\text { Budaya } \\
\mathrm{X}_{2} & =\text { Lingkungan kampus } \\
\mathrm{X}_{3} & =\text { Lingkungan rumah } \\
\mathrm{X}_{4} &
\end{array}
$$


Dari persamaan di atas dapat dijelaskan bahwa :

a) Nilai konstanta sebesar 61,700 mengindikasikan bahwa jika variabel independen yaitu gender, budaya, lingkungan kampus dan lingkungan rumah adalah nol maka nilai ethical beliefs sebesar konstanta 61,700.

b) Apabila variabel gender bernilai satu satuan maka variabel ethical beliefs akan bertambah 0,258 satuan, dengan asumsi/syarat variabel budaya, lingkungan kampus dan lingkungan rumah bernilai tetap/konstan.

c) Apabila variabel budaya bernilai satu satuan maka variabel ethical beliefs akan bertambah 3,353 satuan, dengan asumsi/syarat variabel gender, lingkungan kampus dan lingkungan rumah bernilai tetap/konstan.

d) Apabila variabel lingkungan kampus bernilai satu satuan maka variabel ethical beliefs akan bertambah 0,731 satuan, dengan asumsi/syarat variabel gender, budaya dan lingkungan rumah bernilai tetap/konstan.

e) Apabila variabel lingkungan rumah bernilai satu satuan maka variabel ethical beliefs akan bertambah 0,299 satuan, dengan asumsi/syarat variabel gender, budaya dan lingkungan kampus bernilai tetap/konstan.

\section{Uji Model}

\section{Uji F(F-test)}

Dari hasil analisis data yang diperoleh tentang gender, budaya, lingkungan kampus dan lingkungan rumah terhadap ethical beliefs. Untuk menguji hipotesis ini, maka dilakukan uji $\mathrm{F}$ dengan membandingkan nilai $F_{\text {hitung }}$ dengan $F_{\text {tabel }}$ pada level signifikansi 0,05. Hasil pengolahan statistik analisis regresi menunjukkan nilai $\mathrm{F} 9,366>2,39$ pada level sig $0,000<0,05$. Hal ini menunjukkan bahwa variabel gender, budaya, lingkungan kampus dan lingkungan rumah secara bersama-sama berpengaruh secara signifikan terhadap ethical beliefs pada mahasiswa akuntasi di kota Padang

\section{Uji Koefisien Determinasi $\left(\mathbf{R}^{\mathbf{2}}\right)$}

Berdasarkan pengolahan data SPSS didapat nilai Adjusted $R$ Square menunjukkan 0,096. Hal ini berarti besar kontribusi antara gender, budaya, lingkungan kampus dan lingkungan rumah terhadap ethical beliefs adalah 0,096 atau 9,6\%. Sedangkan sisanya sebesar 0,904 atau 90,4\% disumbangkan oleh faktor lain yang tidak diteliti dalam penelitian ini. Selanjutnya untuk melihat pengaruh secara parsial setiap variabel bebas terhadap variabel terikat dapat dilanjutkan dengan uji t.

\section{Uji Hipotesis (t-test)}

Pengujian hipotesis dilakukan dengan membandingkan (a) nilai sig dengan $\alpha$ yang diajukan yaitu $95 \%$ atau $\alpha=0,05$ dan (b) dengan membandingkan antara $t_{\text {hitung }}$ dengan $t_{\text {tabel. }}$. Hipotesis diterima jika dan signifikansi yang $t_{\text {hitung }}>t_{\text {tabel }}$ dan nilai sig $<0,05$. Berdasarkan nilai $t_{\text {hitung }}$ dan signifikansi yang diperoleh dapat dilihat pada tabel 3.13, maka uji hipotesis $\mathrm{H}_{1}, \mathrm{H}_{2}$, $\mathrm{H}_{3}, \mathrm{H}_{4}$ sedangkan $\mathrm{H}_{5}$ menggunakan uji beda dengan bantuan SPSS versi 21dapat dilakukan sebagai berikut:

\section{Hipotesis pertama}

Hipotesis pertama adalah gender berpengaruh signifikan positif terhadap ethical beliefs. Nilai tabel pada $\alpha=0,05$ adalah 1,960 Nilai $t_{\text {hitung }}$ untuk variabel gender adalah 0,203. Dengan demikian dapat diketahui bahwa $t_{\text {hitung }}>t_{\text {tabel }}$ yaitu 0,203 $>1,960(\operatorname{sig} 0,839>0,05)$ dengan nilai $\beta 0,258$. Hal ini menunjukkan bahwa gender tidak memiliki pengaruh terhadap ethical beliefs, dengan demikian hipotesis pertama ditolak. 


\section{Hipotesis kedua}

Hipotesis kedua adalah budaya berpengaruh signifikan positif terhadap ethical beliefs. Nilai tabel pada $\alpha=0,05$ adalah 1,960 Nilai thitung untuk variabel budaya adalah 2,628. Dengan demikian dapat diketahui bahwa $t_{\text {hitung }}>t_{\text {tabel }}$ yaitu 2,628 $>1,960$ (sig 0,009 $\left.<0,05\right)$ dengan nilai $\beta 3,353$. Hal ini menunjukkan bahwa budaya berpengaruh signifikan positif terhadap ethical beliefs, dengan demikian hipotesis kedua diterima.

\section{Hipotesis ketiga}

Hipotesis ketiga adalah lingkungan rumah berpengaruh signifikan positif terhadap ethical beliefs. Nilai $t_{\text {tabel }}$ pada $\alpha=0,05$ adalah 1,960 Nilai thitung untuk variabel budaya adalah 2,470 . Dengan demikian dapat diketahui bahwa $t_{\text {hitung }}>t_{\text {tabel }}$ yaitu 2,470 $>1,960(\operatorname{sig} 0,0014<$ $0,05)$ dengan nilai $\beta 0,731$. Hal ini menunjukkan bahwa lingkungan kampus berpengaruh signifikan positif terhadap ethical beliefs, dengan demikian hipotesis ketiga diterima.

\section{Hipotesis keempat}

Hipotesis keempat adalah lingkungan rumah berpengaruh signifikan positif terhadap ethical beliefs. Nilai tabel pada $\alpha=0,05$ adalah 1,960 Nilai thitung untuk variabel budaya adalah 2,965. Dengan demikian dapat diketahui bahwa $t_{\text {hitung }}>t_{\text {tabel }}$ yaitu 2,965 $>1,960$ (sig 0,003 < $0,05)$ dengan nilai $\beta 0,299$. Hal ini menunjukkan bahwa budaya berpengruh signifikan positif terhadap ethical beliefs, dengan demikian hipotesis keempat diterima.

\section{Hipotesis kelima}

Hipotesis kelima pada penelitian ini menyatakan bahwa terdapat perbedaan ethical beliefs antara mahasiswa akuntansi awal dengan mahasiswa akuntansi akhir. Pengujian hipotesis kelima menggunakan uji beda, program yang digunakan adalah SPSS versi 21.

Berdasarkan hasil pengolahan data didapat nilai t hitung sebesar 3,556 dan nilai Sig. $(p)$ sebesar 0,000. dimana $t_{\text {hitung }}>t_{\text {tabel }}(3,556>1,960)$ dan nilai Sig. $(p)<$ Sig. $\alpha(0,000<0,05)$, maka Hipotesis kelima diterima. jadi dapat disimpulkan bahwa terdapat perbedaan yang signifikan antara ethical beliefs mahasiswa tingkat akhir dengan ethical beliefs mahasiswa tingkat awal.

\section{PEMBAHASAN}

\section{Mahasiswa Akuntansi Perempuan Memiliki Ethical Beliefs yang Lebih Baik Dibandingkan Mahasiswa Akuntansi Laki-Laki}

Hasil penelitian menunjukan bahwa gender (X1) dalam hal ini mahasiswa perempuan yang telah dan yang belum mengambil mata kuliah audit tidak selalu canderung memiliki ethical beliefs (Y) yang lebih baik jika dihadapkan dalam situasi dilema etis. Hal ini dibuktikan oleh hasil regresi dengan nilai signifikan lebih besar dari level of significant $(0,839>0,05)$ yang berarti variabel X1 tidak berpengaruh signifikan terhadap Y dan nilai koefisien regresi yang menunjukan arah hubungan positif sebesar 0,011 sehingga $\mathrm{H} 1$ ditolak.

Hasil penelitian ini tidak konsisten dengan hasil penelitian yang dilakukan oleh Peterson et al. (2001) dan penelitian yang dilakukan oleh Dawson (1997) menunjukan bahwa perempuan memiliki ethical beliefs yang lebih tinggi dibandingkan laki-laki, perempuan biasanya akan lebih tegas dalam berperilaku etis maupun menanggapi individu lain yang melanggar etika. Hal ini disebabkan karena perempuan lebih berhati-hati dalam mengambil suatu tindakan dan berusaha untuk menghindari risiko yang dapat merugikan dirinya dalam jangka panjang.

Namun hasil penelitian ini sejalan dengan hasil penelitian terdahulu yang dilakukan oleh Revita (2014) yang mengatakan laki-laki dan perempuan memiliki persepsi yang sama 
atas perilaku tidak etis akuntan. Juga ditemukan dalam penelitian yang dilakukan oleh Sikula \& Costa (1994) yang tidak menemukan perbedaan signifikan yang disebabkan oleh gender.

Hal ini sesuai dengan pendekatan sosialisasi struktural, dimana laki-laki dan perempuan akan membentuk sikap yang sama dalam merespon hal yang berkaitan dengan perilaku etis. Pendekatan struktural menurut Coate dan Frey (2000), menyatakan bahwa perbedaan antara laki-laki dan perempuan disebabkan oleh sosialisasi awal terhadap pekerjaan dan kebutuhan peran lainnya. Sosialisasi awal dipengaruhi oleh imbalan (rewards) dan biaya yang berhubungan dengan peran-peran dalam pekerjaan. Karena sifat dan pekerjaan yang sedang dijalani membentuk perilaku melalui struktur imbalan (rewards), laki-laki dan perempuan akan merespon isu-isu etika secara sama dalam lingkungan pekerjaan yang sama. Pendekatan struktural memprediksi bahwa laki-laki dan perempuan dalam pekerjaan yang sudah ada atau dalam training untuk pekerjaan-pekerjaan khusus akan menunjukkan prioritas etis yang sama

Dengan kata lain mahasiswa akuntansi perempuan memiliki ethical beliefs yang sama dengan laki-laki. Hal ini muncul karena adanya persamaan pemahaman, pengetahuan dan kesamaan peran serta impian dalam pencapaian karier untuk memperoleh reward dan insentif, sehingga menjadikan mahasiswa akuntansi perempuan yang telah dan yang belum mengambil mata kuliah audit tidak selalu memiliki ethical beliefs yang lebih tinggi dari laki-laki.

\section{Mahasiswa Akuntansi Minang Memiliki Ethical Beliefs yang Lebih Baik Dibandingkan Mahasiswa Akuntansi Non Minang}

Hipotesis kedua $\left(\mathrm{H}_{2}\right)$ yang diajukan peneliti dalam penelitian ini yaitu budaya (X2) berpengaruh positif terhadap ethical beliefs $(\mathrm{Y})$ mahasiswa akuntansi yang telah maupun yang belum mengambil mata kuliah audit. Hal ini dibuktikan oleh hasil analisis regresi dengan nilai signifikan lebih kecil dari level of significant $(0,09<0,05)$ yang berarti variabel X2 berpengaruh signifikan terhadap $\mathrm{Y}$ dan nilai koefisien regresi menunjukan arah hubungan positif sebesar 0,140 sehingga $\mathrm{H} 2$ diterima.

Hasil penelitian ini mendukung penelitian yang dilakukan oleh Rawwas et al. (2014) bahwa budaya berpengaruh signifikan positif terhadap ethical beliefs. Hoffman et al. (2002) menyatakan bahwa perbedaan budaya akan mempengaruhi perbedaan ethical beliefs seseorang. Dalam penelitian ini budaya Minang memiliki ethical beliefs yang baik dari pada budaya non Minang. Hal ini dikarenakan budaya minang memiliki pandangan hidup sendiri yang berbeda dengan pandangan hidup budaya lainnya. Pandangan hidup orang Minang tertuang dalam ketentuan yang disebut dengan adat minangkabau "adat basandi syara', syara" basandi kitabullah" (adat bersendikan hukum, hukum bersendikan Al-Qur'an) yang berarti adat berlandaskan ajaran islam (Navis, 1984).

\section{Pengaruh Lingkungan Kampus terhadap Ethical Beliefs pada Mahasiswa S1 Akuntansi di Kota Padang}

Hipotesis ketiga $\left(\mathrm{H}_{3}\right)$ yang diajukan peneliti dalam penelitian ini yaitu lingkungan kampus (X3) berpengaruh signifikan positif terhadap ethical beliefs (Y) mahasiswa akuntansi yang telah maupun yang belum mengambil mata kuliah audit. Hal ini dibuktikan oleh hasil analisis regresi dengan nilai signifikan lebih kecil dari level of significant $(0,014<0,05)$ yang berarti variabel X3 berpengaruh signifikan terhadap Y dan nilai koefisien regresi menunjukan arah hubungan positif sebesar 0,133 sehingga $\mathrm{H} 3$ diterima.

Penelitian ini mendukung penelitian yang dilakukan oleh Peterson (2002) yang menyatakan bahwa ethical beliefs seseorang dipengaruhi oleh lingkungan tempat mereka berinteraksi. Perryer dan Jordan (2002) bahwa lingkungan kampus berpengaruh signifikan positif terhadap ethical beliefs individu. Artinya, semakin baik lingkungan kampus mahasiswa maka mahasiswa tersebut akan memiliki ethical beliefs yang baik. 


\section{Pengaruh Lingkungan Rumah terhadap Ethical Beliefs pada Mahasiswa S1 Akuntansi di Kota Padang}

Hipotesis keempat $\left(\mathrm{H}_{4}\right)$ yang diajukan peneliti dalam penelitian ini yaitu lingkungan rumah (X4) berpengaruh positif terhadap ethical beliefs (Y) mahasiswa akuntansi yang telah maupun yang belum mengambil mata kuliah audit. Hal ini dibuktikan oleh hasil analisis regresi dengan nilai signifikan lebih kecil dari level of significant $(0,03<0,05)$ yang berarti variabel $\mathrm{X} 4$ berpengaruh signifikan terhadap $\mathrm{Y}$ dan nilai koefisien regresi menunjukan arah hubungan positif sebesar 0,163 sehingga $\mathrm{H} 2$ diterima.

Penelitian ini sejalan dengan penelitian yang dilakukan oleh Perryer dan Jordan (2002) menyatakan lingkungan rumah menjadi prediktor perilaku etis. Artinya, apabila sosialisasi seseorang di lingkungan rumahnya baik maka seseorang tersebut akan memiliki ethical beliefs yang baik. Hal ini tampaknya bahwa nilai-nilai yang diperoleh dari rumah melalui proses sosialisasi selama masa kanak-kanak dan melalui perkembangan moral pada umumnya akan mempengaruhi sikap dalam masalah etika (Peterson et al., 2001).

\section{Terdapat Perbedaan Ethical Beliefs antara Mahasiswa S1 Akuntansi Tingkat Awal dan Mahasiswa S1 Akuntansi Tingkat Akhir di Kota Padang}

Hipotesis kelima $\left(\mathrm{H}_{5}\right)$ yang diajukan peneliti dalam penelitian ini yaitu terdapat perbedaan ethical beliefs antara mahasiswa akuntansi tingkat awal dan mahasiswa akuntansi tingkat akhir. Dimana diketahui memiliki nilai $t_{\text {hitung }}>t_{\text {tabel }}(3,556>1,960)$ dan nilai Sig. $(p)$ $<$ Sig. $\alpha(0,000<0,05)$, maka H5 diterima. Dapat disimpulkan bahwa terdapat perbedaan ethical beliefs mahasiswa akuntansi tingkat akhir dengan ethical beliefs mahasiswa akuntansi tingkat awal.

Kesimpulan dari hasil diatas dapat dikuatkan dengan hasil mean yang telah didapatkan, dimana mean untuk ethical beliefs mahasiswa akuntansi tingkat akhir sebesar 95,06 sedangkan mean untuk ethical beliefs mahasiswa akuntansi tingkat awal sebesar 90,47, hal tersebut berarti bahwa ethical beliefs mahasiswa akuntansi tingkat akhir lebih tinggi dari ethical beliefs mahasiswa akuntansi tingkat awal.

Penelitian ini mendukung penelitian yang dilakukan oleh Yulianti dan Fitriany (2005) menemukan bahwa mahasiswa akuntansi tingkat awal dan mahasiswa tingkat akhir berbeda dalam penilaian etis. Risa (2010) menyatakan bahwa mahasiswa tingkat akhir memiliki persepsi etis yang lebih baik dibandingkan dengan mahasiswa tingkat awal.

\section{SIMPULAN, KETERBATASAN DAN SARAN Simpulan} berikut:

Berdasarkan hasil penelitian dan pembahasan maka dapat ditarik kesimpulan sebagai

1. Dalam penelitian ini tidak dapat membuktikan bahwa perempuan memiliki Ethical Beliefs yang lebih baik dari pada laki-laki.

2. Dalam penelitian ini dapat menunjukkan bahwa terdapat pengaruh yang positif antara budaya terhadap Ethical Beliefs.

3. Dalam penelitian ini dapat menunjukkan bahwa terdapat pengaruh yang positif antara lingkungan kampus terhadap Ethical Beliefs.

4. Dalam penelitian ini dapat menunjukkan bahwa terdapat pengaruh yang positif antara lingkungan rumah terhadap Ethical Beliefs. 
5. Dalam penelitian ini dapat menunjukkan bahwa terdapat perbedaan ethical beliefs antara mahasiswa akuntansi tingkat awal dengan mahasiswa akuntansi tingkat akhir.

\section{Keterbatasan Penelitian}

Meskipun peneliti telah berusaha merancang dan mengembangkan penelitian sedemikianrupa, namun masih terdapat beberapa keterbatasan dalam penelitian ini yaitu:

1. Ruang lingkup penelitian ini hanya dilakukan di Kota Padang sehingga untuk mendapatkan kesimpulan yang bersifat umum perlu dilakukan penelitian yang lebih luas.

2. Penelitian ini merupakan metode survei menggunakan kuesioner tanpa dilengkapi dengan wawancara dan peneliti tidak mampu mengontrol secara ketat seluruh pernyataan responden yang mengisi kuesioner penelitian untuk mengumpulkan data penelitian terhadap tingkat kejujuran responden sehingga terkadang jawaban yang diberikan oleh responden tidak menunjukan keadaan sesungguhnya.

3. Walaupun dalam pengisian angket sudah diupayakan secara teliti dan hati-hati, tentunya hal tersebut juga tidak lepas dari kemungkinan adanya responden yang mengisi kuisioner dengan tidak serius dan asal-asalan.

\section{Saran}

Berdasarkan pembahasan dan kesimpulan di atas, maka penulis memberikan saran sebagai berikut:

1. Peneliti berikutnya dapat melakukan penelitian di Kota lain, sehingga nantinya hasilnya bisa digeneralisasi untuk lingkup yang lebih luas untuk memperkuat validitas eksternal diperlukan peneliti lebih lanjut.

2. Penelitian berikutnya sebaiknya tidak hanya menggunakan kuesioner saja, ada baiknya juga melakukan wawancara secara langsung kepada responden atau menggunakan kuesioner eksperimen untuk meminimalisasi kelemahan internal validity.

3. Hasil penelitian ini yaitu ethical beliefs mahasiswa akuntansi yang telah maupun yang belum mengambil mata kuliah audit hanya bisa dijelaskan sebesar 9,6\% oleh ke 4 variabel bebas ( $g$ ender, budaya, lingkungan kampus dan lingkungan rumah), untuk penelitian yang akan datang sebaiknya meneliti variabel-variabel lain yang mempengaruhi ethical beliefs mahasiswa akuntansi yang telah maupun yang belum mengambil mata kuliah audit seperti: usia dan religiusitas.

\section{DAFTAR PUSTAKA}

Arikunto, S. 2009. Dasar-dasar Evaluasi pendidikan. Jakarta: Bumi Aksara

Agoes, Sukrisno, Ardana \& I Cenik. 2011. Etika Bisnis dan Profesi : Tantangan Membangun Manusia Seutuhnya. Jakarta: Salemba Empat

Chung, J. and G. S. Monroe. 2003. "A Research Note on The Effect of Gender and Task Complexity on Audit judgment".Journal of Behavioral Research,13, hal .111-125.

Coate and Frey. 2000. "Some Evidence on the Ethical Disposition of Accounting Students : Context and Gender Implications". TeachingBusiness Ethis. Vol 4 No 4, pp 379-404.

Dewanti, Diwi. 2015."Pengaruh Orientasi Etis dan Gender terhadap Persepsi Mahasiswa mengenai Perilaku Tidak Etis Akuntan (Studi Empiris Mahasiswa S1 Akuntansi Universitas Negeri Yogyakarta)". Skripsi. Universitas Negeri Yogyakarta

Dawson, L. M. 1995."Women and men, morality and ethics". Business Horizons (JuliAgustus), 61-68.1

Duska, Ronald F and Brenda Shay Duska. 2011. Accounting Ethics. United Kingdom: Blackwell Publishing. E-Book 
Falah, Syaikhul. 2006. "Pengaruh Budaya Etis Organisasi dan Orientasi Etika Terhadap Sensitivitas Etika (Studi Empiris Tentang Pemeriksaan Internal di Bawasda Pemda Papua)". Tesis Universitas Diponegoro. Semarang

Farisi, Salman Al. 2013. "Pengaruh Lingkungan keluarga, Konsep Diri, dan Iklim Sosial terhadap Kemandirian Siswa SMKN 3 Yogyakarta. Skripsi

Ghozali, Imam. 2005. Aplikasi Analisis Multivariat dengan Program SPSS. Semarang: Universitas Diponrgoro.

Gilligan, C. 1982. In a different voice. Cambridge, MA.: Harvard University Press.

Herman, Sofyandi. 2008. Manajemen Sumber Daya Manusia. Yogyakarta : Graha. Herwinda. 2010. "Persepsi Mahasiswa Atas Perilaku Tidak Etis Akuntan". Skripsi. Fakultas Ekonomi Universitas Diponegoro.

Hunt, A. 1997."Are women more ethical than men? "Baylor Business Review, 15(1), 7.

Hunt, Shelby D. and Scott J. Vitell. (1993). "The General Theory of Marketing Ethics: A Retrospective and Revision, in Smith N. Craig and John A. Quelch (ed.) Ethics in Marketing” (Irwin Inc., Homewood, IL), pp. 775-784

Hurlock, E.B. 2002. Psikologi Perkembangan. 5th edition. Erlanga: Jakarta.

Idris. 2010. Model Aplikasi Analisis Data Kuantitatif dengan Program SPSS Edisi Revisi III.UNP : Padang.

Jamilah et al. 2007. "Pengaruh Gender,Tekanan Ketaatan, DanKompleksitas Tugas Terhadap Audit Judgment." SNA XMakasar. 26-28 Juli.

KBBI Online. 2016. Kamus Besar Bahasa Indonesia [online] tersedia pada (www.pusatbahasa.diknas.go.id/kbbi). Diakses 24 Maret 2018.

Kenhove, Patrick Van., dkk. 2001."An Empirical Investigation of the Relationships between Ethical Beliefs, Ethical Ideology, Political Preference and Need for Closure. Jounal of Business Ethich: 347-361.

Kohlberg, Lawrence. 1973. "The Claim to Moral Adequacy of a Highest Stage of Moral Judgment". Journal of Philosophy70: 630-646.

Monks, F. J., dkk. 2006. Psikologi Perkembangan: Pengantar dalam Berbagai Bagiannya. Yogyakarta: Gajah Mada University Press

Navis, A.,A. 1984. Alam Takambang Jadi Guru. Jakarta: PT. Pustaka Grafitipers.

Nitisemito, A., S. 2003. Manajemen Personalia, Ghalia Indonesia, Jakarta

Nugraha, Aditya Purba. 2015. "Pengaruh Gender, Pengalaman, Keahlian Auditor dan Tekanan Ketaatan terhadap Auditor Judgment dengan Kompleksitas tugas sebagai Variabel Moderating pada BPK Jawa Tengah”. Skripsi Fakultas Ekonomika dan Bisnis Universitas Diponegoro, Semarang

Pamela, Astriana. 2014. "Pengaruh Pemahaman Kode Etik Profesi Akuntan terhadap Perilaku Etis (Studi Empiris Mahasiswa Akuntansi Universitas Negeri Yogyakarta )”. Skripsi Universitas Negeri Yogyakarta

Peterson, D., Rhoads, A., \& Vaught, B. C. 2001. "Ethical beliefs of business professionals: A study of gender, age and external factors". Journal of Business Ethics (31), 225-232.

Perryer, Chris dan Lheighton, Catherine. 2002. "The Influence of Gender, Age, Culture and other Factors on Ethical Beliefs: A Comparative Study in Australia and Singapore”. Public Administration \& Management: An Interactive Journal, 7(4), 367-382.

Rawwas, M., Swaidan, Z., \& Isakson, H. 2007. "A comparative study of ethical beliefs of master of business administration students in the United States with those in Hong Kong". Journal of Education for Business, 82(3), 146-158.

Revita, Mardawati. 2016. "The Influence of Ethical Orientation, Gender, dan Ethics Knowledge on The Perception of Accounting Students on Accountant's Unethical Behavior. "Jurnal profita edisi 6 tahun 
Sarwono, W. Sarlito. 2015. Psikologi Lintas Budaya. PT Raja Grafindo Persada, Jakarta

Schiffman, L. G. \& Kanuk, L. L. 2008."Consumer behavior (7 th ed)". International Edition, Upper Saddle River, New Jersey: Prentice Hall.

Sikula, A., \& Costa, A. D. (1994). Are women more ethical than men? Journal of Business Ethics, 13, 859-871

Sedarmayanti. 2001. Sumber daya Manusia dan Produktivitas Kerja Mandar Maju. Bandung

Slameto.2003. Belajar dan Faktor-Faktor yang Mempengaruhinya. Jakarta : Bineka Cipta

Sugiyono.2010. Metode Penelitian Bisnis (Pendekatan Kuantitatif, Kualitatif, dan R\&D). Bandung: CV. Alfabeta.

Sudjana, Nana. 2002. Metode Statistik. Bandung: PT Tarsito.

Syarifuddin, Amir. 1984. Pelaksanaan Hukum Kewarisan Islam dalam Lingkungan Adat Minangkabau. Jakarta: PT Gunung Agung.

Utami, Ristianawati Dwi. 2011. "Pengaruh Family Structure terhadap Materialitas dan Pembelian Kompulsif pada Remaja”. Jurnal Manajemen Teori dan Terapan | Tahun 4, No. 3,

Velasquez, Manuel G. 2005. Etika Bisnis, konsep dan kasus - edisi 5. Diterjemahkan: Ana Purwaningsih, Kurniato dan Totok Budisantoso. Yogyakarta: ANDI

Wibowo, Agus. 2016. "Hubungan Lingkungan Kampus, Pola Asuh Orang Tua dan Motiavasi berprestasi Mahasiswa.” Jurnal Fakultas Ekonomi Universitas Negeri Jakarta

www.spss.indonesia.com diakses tanggal 20 Desember 2018

www.kompas.com diakses tanggal 19 Maret 2018 
LAMPIRAN

Uji Normalitas

One-Sample Kolmogorov-Smirnov Test

\begin{tabular}{|ll|r|}
\hline & & \multicolumn{1}{|c|}{ Unstandardized Residual } \\
\hline Normal Parameters & 356 \\
& Mean & .0000000 \\
Most Extreme Differences & Std. Deviation & 10.45602115 \\
& Absolute & .059 \\
& Positive & .034 \\
& Negative &. .059 \\
Kolmogorov-Smirnov Z & & 1.118 \\
Asymp. Sig. (2-tailed) & & .164 \\
\hline
\end{tabular}

a. Test distribution is Normal.

b. Calculated from data.

\section{Uji Autokorelasi}

Model Summary

\begin{tabular}{|c|r|r|r|r|r|}
\hline Model & & & \multicolumn{2}{|c|}{$\begin{array}{c}\text { Std. Error of the } \\
\text { Estimate }\end{array}$} & Durbin-Watson \\
\hline-1 & $\mathrm{R}$ & $\mathrm{R}$ Square & Adjusted R Square & 10.515 & 1.469 \\
\hline
\end{tabular}

a. Predictors: (Constant), Lingkungan Rumah (X4), Gender (X1), Budaya (X2), Lingkungan Kampus (X3)

b. Dependent Variable: Ethical Beliefs $(Y)$

\begin{tabular}{|c|c|c|c|}
\hline \multicolumn{4}{|c|}{$\begin{array}{c}\text { Uji Multikolinieritas } \\
\text { Coefficients }^{a}\end{array}$} \\
\hline \multirow{2}{*}{\multicolumn{2}{|c|}{ Model }} & \multicolumn{2}{|c|}{ Collinearity Statistics } \\
\hline & & Tolerance & VIF \\
\hline 1 & (Constant) & & \\
\hline & Gender (X1) & .926 & 1.080 \\
\hline & Budaya (X2) & .903 & 1.108 \\
\hline & Lingkungan Kampus (X3) & .885 & 1.130 \\
\hline & Lingkungan Rumah (X4) & .854 & 1.171 \\
\hline
\end{tabular}

a. Dependent Variable: Ethical Beliefs (Y)

Analisis Regresi Berganda - Uji Hipotesis

Variables Entered/Removed ${ }^{\mathrm{b}}$

\begin{tabular}{|c|l|c|l|}
\hline Model & \multicolumn{1}{|c|}{ Variables Entered } & Variables Removed & Method \\
\hline 1 & $\begin{array}{l}\text { Lingkungan Rumah (X4), Gender (X1), } \\
\text { Budaya (X2), Lingkungan Kampus (X3) }\end{array}$ &. & Enter \\
\hline
\end{tabular}

a. All requested variables entered.

b. Dependent Variable: Ethical Beliefs $(Y)$

\begin{tabular}{|ll|r|r|r|r|r|}
\hline Model & & Sum of Squares & \multicolumn{1}{|c|}{ Df } & Mean Square & F & Sig. \\
\hline 1 & Regression & 4142.457 & 4 & 1035.614 & 9.366 & $.000^{\text {a }}$ \\
& Residual & 38811.574 & 351 & 110.574 & & \\
& Total & 42954.031 & 355 & & & \\
\hline
\end{tabular}

a. Predictors: (Constant), Lingkungan Rumah (X4), Gender (X1), Budaya (X2), Lingkungan Kampus (X3)

b. Dependent Variable: Ethical Beliefs $(\mathrm{Y})$ 
Coefficients $^{a}$

\begin{tabular}{|c|c|c|c|c|c|}
\hline \multirow[t]{2}{*}{ Model } & \multicolumn{2}{|c|}{ Unstandardized Coefficients } & \multirow{2}{*}{$\frac{\text { Standardized Coefficients }}{\text { Beta }}$} & \multirow[b]{2}{*}{$\mathrm{t}$} & \multirow[b]{2}{*}{ Sig. } \\
\hline & $\mathrm{B}$ & Std. Error & & & \\
\hline 1 (Constant) & 61.700 & 6.178 & & 9.988 & .000 \\
\hline Gender (X1) & .258 & 1.270 & .011 & .203 & .839 \\
\hline Budaya (X2) & 3.353 & 1.276 & .140 & 2.628 & .009 \\
\hline Lingkungan Kampus (X3) & .731 & .296 & .133 & 2.470 & .014 \\
\hline Lingkungan Rumah (X4) & .299 & .101 & .163 & 2.965 & .003 \\
\hline
\end{tabular}

a. Dependent Variable: Ethical Beliefs (Y)

Uji Persyaratan Analisis

Uji Normalitas

One-Sample Kolmogorov-Smirnov Test

\begin{tabular}{|ll|r|r|}
\hline & & Y_Akhir & Y_Awal \\
\hline N & & 96 & 260 \\
Normal Parameters & Mean & 95.0625 & 90.4654 \\
& Std. Deviation & 9.63635 & 11.22784 \\
Most Extreme Differences & .081 & .082 \\
& Absolute & .081 & .052 \\
& Positive & -.065 & -.082 \\
Kolmogorov-Smirnov Z & Negative & .793 & 1.316 \\
Asymp. Sig. (2-tailed) & & .555 & .063 \\
\hline
\end{tabular}

a. Test distribution is Normal.

b. Calculated from data.

Uji Homogenitas

Test of Homogeneity of Variances

Ethical Beliefs ( $\mathrm{Y}$ )

\begin{tabular}{|c|c|c|c|}
\hline Levene Statistic & $\mathrm{df1}$ & $\mathrm{df} 2$ & Sig. \\
\hline 3.246 & $\overline{1}$ & 354 & .072 \\
\hline
\end{tabular}

Uji Beda - Uji t (independent sample t test) Group Statistics

\begin{tabular}{|ll|r|r|r|r|}
\hline \multicolumn{2}{|c|}{ Tingkat } & $\mathrm{N}$ & Mean & $\begin{array}{c}\text { Std. } \\
\text { Deviation }\end{array}$ & $\begin{array}{c}\text { Std. Error } \\
\text { Mean }\end{array}$ \\
\hline Ethical Beliefs & Mahasiswa Tingkat Akhir & 96 & 95.06 & 9.636 & .984 \\
$(\mathrm{Y})$ & Mahasiswa Tingkat Awal & 260 & 90.47 & 11.228 & .696 \\
\hline
\end{tabular}

Independent Samples Test

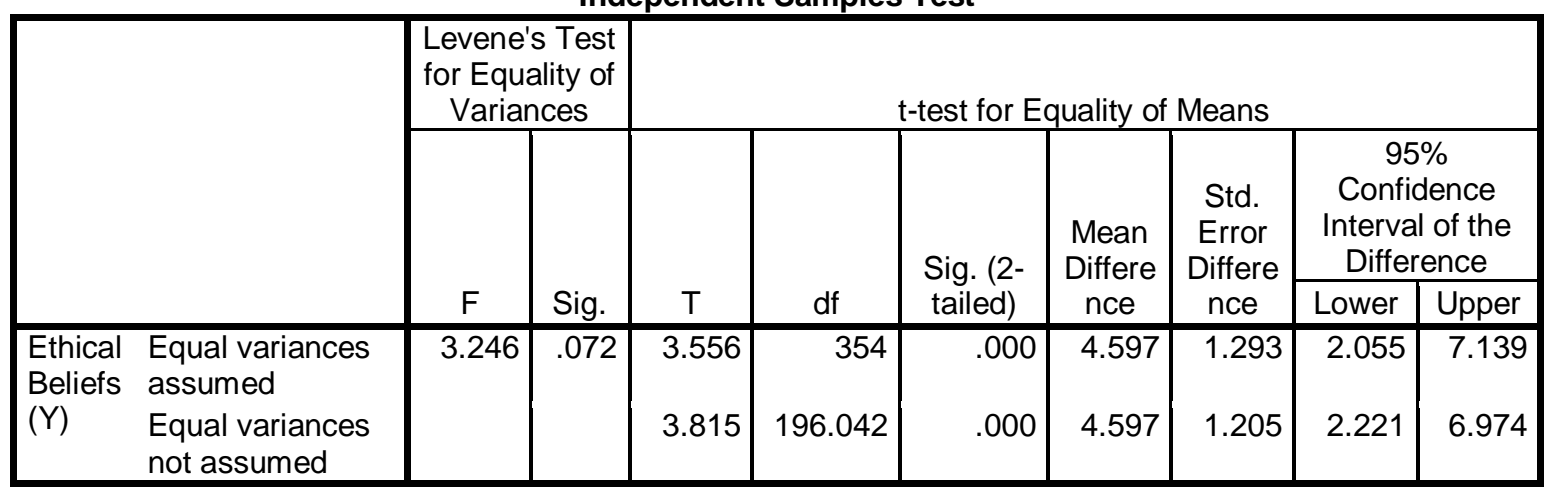

